\title{
Keberadaan Instruksi Presiden Sebagai Produk Hukum Di Indonesia
}

\author{
Ali Marwan Hsb*
}

\begin{abstract}
Abstrak
Penggunaan kata pribumi oleh Gubernur Daerah Khusus Ibukota Jakarta menimbulkan pro dan kontra. Hal ini terkait dengan adanya Instruksi Presiden Nomor 26 Tahun 1998 tentang Menghentikan Penggunaan Istilah Pribumi dan Non-Pribumi. Rumusan masalah bagaimana keberadaan instruksi presiden sebagai produk hukum di Indonesia? Tujuan untuk menganalisis keberadaan instruksi presiden sebagai produk hukum di Indonesia. Kegunaannya yaitu dapat memberikan wawasan kepada masyarakat secara umum tentang keberadaan instruksi presiden sebagai produk hukum di Indonesia. Metode penelitian yaitu yuridis normatif. Hasil penelitian yaitu bahwa instruksi presiden bukan merupakan peraturan perundang-undangan yang bersifat mengatur. Instruksi presiden hanyalah suatu peraturan kebijakan yang bersifat menuntun, memberi arahan kebijakan dan mengatur suatu pelaksanaan tugas dan pekerjaan. Sehingga tidak ada jenis sanksi yang dapat diberikan jika instruksi tersebut dilanggar. Oleh karena itu, jika kemudian materi dari instruksi presiden tersebut dirasa masih layak dipertahankan dan masih dibutuhkandisarankan agar materi muatannya dimasukkan ke dalam materi muatan undang-undang. Sehingga, lebih mempunyai kekuatan hukum yang mengikat dan dapat dimasukkan sanksi bagi siapa yang melanggar ketentuan tersebut. Kesimpulan bahwa keberadaan instruksi presiden bukan merupakan peraturan perundang-undangan yang bersifat mengatur, namun kebijakan yang bersifat menuntun, memberi arahan kebijakan dan mengatur suatu pelaksanaan tugas dan pekerjaan.
\end{abstract}

Kata Kunci: Instruksi Presiden, Produk Hukum, Indonesia

\section{The Existence Of Presidential Instructions As Legal Products In Indonesia}

\begin{abstract}
The use of the indigenous by the Governor of the Special Capital Region of Jakarta raises pros and cons. This is related to the Presidential Instruction Number 26 of 1998 on Stopping the Use of Indigenous and Non-Indigenous Terms. So that this paper will be examined in relation to the existence of presidential instructions. Based on the search, it was found that the president's instructions were not legislation. The presidential instruction is only a policy that is guiding, gives policy direction and regulates the implementation of duties and work. So that there is no type of sanction that can be given if the instruction is violated. Therefore, if later the material from the presidential instruction was deemed worthy of being maintained and still needed, it was suggested that the content material be included in
\end{abstract}

\footnotetext{
*E-mail : ali_marwan@ rocketmail.com dan ali.marwan13@gmail.com
} 
the content of the law. Thus, it has more binding legal force and sanctions can be included for those who violate these provisions.

Keywords: Presidential Instruction, Legal Product, Indonesia.

\section{Pendahuluan}

Gubernur Daerah Khusus Ibukota Jakarta terpilih, Anies Baswedan, dalam pidato pertamanya sebagai Gubernur menjadi perbincangan di jagad media sosial. Hal ini terkait dengan penyebutan kata "pribumi”. Isi pidatonya langsung mengentak publik. Melalui media sosial, netizen ramai yang mempertanyakan istilah pribumi yang dikemukakan. (Website Jogja Tribun News).

Setelah ramai diperbincangkan, kemudian ditemukan ternyata ada instruksi presiden (Inpres) yang mengatur mengenai pelarangan penggunaan kata pribumi dan non-pribumi yaitu Instruksi Presiden Nomor 26 Tahun 1998 tentang Menghentikan Penggunaan Istilah Pribumi dan Non Pribumi yang dikeluarkan pada 16 September 1998 di masa pemerintahan Presiden B.J. Habibie. Dalam Inpres tersebut ada 5 (lima) instruksi presiden yang ditujukan kepada para Menteri, para Pimpinan Lembaga Pemerintah Non Departemen, para Pimpinan Kesekretariatan Lembaga Tertinggi/Tinggi Negara dan para Gubernur Kepala Daerah Tingkat I dan Bupati/Walikotamadya Kepala Daerah Tingkat II, yang isi lengkapnya sebagai berikut:

Pertama: Menghentikan penggunaan istilah pribumi dan non pribumi dalam semua perumusan dan penyelenggaraan kebijakan, perencanaan program, ataupun pelaksanaan kegiatan penyelenggaraan pemerintahan.

Kedua: Memberikan perlakuan dan layanan yang sama kepada seluruh warga negara Indonesia dalam penyelenggaraan layanan pemerintahan, kemasyarakatan dan pembangunan, dan meniadakan pembedaan dalam segala bentuk, sifat serta tingkatan kepada warga negara Indonesia baik atas dasar suku, agama, ras maupun asal-usul dalam penyelenggaraan layanan tersebut.

Ketiga: Meninjau kembali dan menyesuaikan seluruh peraturan perundangundangan, kebijakan, program dan kegiatan yang selama ini telah 
ditetapkan dan dilaksanakan, termasuk antara lain dalam pemberian layanan perizinan usaha, keuangan/perbankan, kependudukan, pendidikan, kesehatan, kesempatan kerja dan penentuan gaji atau penghasilan dan hak-hak pekerja lainnya, sesuai dengan Instruksi Presiden ini.

Keempat: Para Menteri, Pimpinan Lembaga Pemerintah Non Departemen, Gubernur Kepala Daerah Tingkat I Bupati/Walikotamadya Kepala Daerah Tingkat II melakukan pembinaan dalam sektor dan wilayah masing-masing terhadap pelaksanaan Instruksi Presiden ini di kalangan dunia usaha dan masyarakat yang menyelenggarakan kegiatas atas dasar perizinan yang diberikan atas dasar kewenangan yang dimilikinya.

Kelima: Menteri Koordinator Bidang Politik dan Keamanan mengkoordinasi pelaksanaan instruksi ini dikalangan para Menteri dan pejabat-pejabat lainnya yang disebut dalam Instruksi Presiden ini.

Tanpa ingin mengomentari pro dan kontra terkait dengan penggunaan kata pribumi oleh Gubernur DKI Jakarta dalam pidatonya, dalam tulisan ini akan ditelusuri bagaimana sebenarnya keberadaan Instruksi Presiden dalam hierarki peraturan perundang-undangan di Indonesia saat ini.

\section{Pembahasan}

\section{A. Bentuk Produk Hukum}

Hukum tertulis (geschreven recht) menurut Soedjono Dirdjosisworo dalam buku Pengantar Ilmu Hukum, adalah hukum yang mencakup perundangundangan dalam berbagai bentuk yang dibuat oleh pembuat undang-undang dan traktak yang dihasilkan dari hubungan internasional (Dirdjosisworo, 1994: 215). Hukum tertulis telah menjadi tanda ciri dari hukum modern yang mengatur serta melayani hukum modern (Rahardjo, 2000: 72). Kelebihan hukum tertulis 
dibanding hukum tidak tertulisdalam melayani kehidupan modern adalah antara lain:(Dirdjosisworo, 1994: 214):

1. Apa yang diatur dengan mudah diketahui orang.

2. Setiap orang, kecuali yang tidak bisa membaca, mendapatkan jalan masuk yang sama ke dalam hukum.

3. Pengetahuan orang mengenai hukum senantiasa bisa dicocokkan kembali dengan yang telah dituliskan, sehingga mengurangi kepastian.

4. Untuk keperluan pengembangan peraturan hukum atau perundangundangan, untuk membuat yang baru, maka hukum tertulis juga menyediakan banyak kekurangan.

Adapun sifat produk hukum tertulis dibedakan atas:

a. Pengaturan (regeling).

Peraturan adalah instrumen hukum yang bersifat umum, berisi pengaturan, berlaku serta mengikat untuk umum.(Ridwan HR, 2006: 133 - 148) Dari sisi teoretis, peraturan(regeling) mempunyai sifat-sifat khusus, yakni: (Pantja \& Na'a, 2008: 18):
a) Norma hukum (rechtsnormen);
b) Berlaku keluar (naarbuitenwerken);
c) Bersifat umum dalam arti luas;
d) Bersifat futuristik;
e) Berlaku terus menerus (dauerhaftig);
f) Bersifat hierarkis (stufenbaudesrechts).

b. Penetapan/keputusan (beschikking).

Pengertian beschikking diperkenalkan di Belanda oleh van der Pot dan Van Vollenhoven dan masuk ke Indonesia melalui Prins. Istilah dalam bahasa Perancis disebut dengan acte administratif, dan dalam hukum Jerman oleh Otto Meyer disebut dengan verwaltungsakt. Prins mendefenisikan keputusan sebagai suatu tindakan hukum yang bersifat sepihak dalam bidang pemerintahan, dilakukan oleh suatu badan pemerintah berdasarkan wewenangnya yang luar biasa.(Adisapoetra, 1978: 42). Untuk defensi penetapan tidak ada salahnya mengutip pendapat Prayudi yang mengatakan 
penetapan adalah perbuatan hukum sepihakyang bersifat administrasi negara dilakukan oleh pejahat atau instansi penguasa (negara) yang berwenang dan berwajib khusus untuk itu. Setidaknya dari defenisi yang dikemukakan oleh Prins tersebut terkandung 5 unsur yaitu:

1. Adanya tindakan hukum;

2. Bersifat sepihak;

3. Dalam bidang pemerintahan;

4. Dilakukan oleh badan pemerintah; dan

5. Berdasarkan wewenangnya yang luar biasa.

Antara pengaturan dan penetapan/keputusan sebenarnya memiliki perbedaan. Setidaknya perbedaan tersebut tercermin dalam tiga hal berikut ini:

1) Perbedaan isi dan sifat.

Peraturan berisi norma hukum yang berlaku dan mengikat umum (regeling).Keputusan berisi suatu penetapan atau keputusan yang sifatnya individual, final, dan konkret.

2) Perbedaan cara melawannya.

Upaya hukum untuk melawan/menggugat peraturan dilakukan melalui mekanisme pengujian peraturan perundang-undangan (judicial review). Untuk undang-undang melalui Mahkamah Konstitusi, sedang untuk peraturan perundang-undangan dibawah undang-undang melalui Mahkamah Agung.Upaya hukum untuk melawan/membatalkan keputusan dilakukan melalui Pengadilan Tata Usaha Negara.

3) Perbedaan kekuatan berlaku dan mengikatnya.

Dengan diundangkannya suatu peraturan di dalam Lembaran Negara atau Berita Negara, maka peraturan tersebut memiliki daya berlaku dan mengikat umum (binding force). Sebagaimana dinyatakan dalam Pasal 87 Undang-Undang Nomor 12 Tahun 2011 tentang Pembentukan Peraturan Perundang-undangan, "Peraturan Perundang-undangan mulai berlaku dan mempunyai kekuatan mengikat pada tanggal diundangkan, kecuali ditentukan lain di dalam Peraturan Perundang-undangan yang bersangkutan." Hal tersebut dimaksudkan agar semua orang mengetahui 
adanya peraturan yang dimaksud sehingga dengan dimikian berlakulah asas fiksi hukum "Iedereen wordht geacht de wet te kennen." Artinya setiap orang dianggap mengetahui hukum. Oleh karena itu tidak ada alasan bagi yang melanggar hukum bahwa ia tidak mengetahui hukumnya.(Dewi \&Yaqin, 2012: 54). Suatu keputusan/ketetapan tidak dipersyaratkan untuk diundangkan dalam Lembaran Negara atau Berita Negara karena keputusan/ketetapan tidak dimaksudkan untuk berlaku dan mengikat umum.

Untuk jenisnya, produk hukum tertulis dibedakan atas:

a. Peraturan perundang-undangan;

b. Peraturan kebijakan (pseudowetsgeving/beleidsregel/administrative rules), contohnya:Keputusan,Surat Edaran, dan Instruksi.

c. Hukum tertulis yang tidak termasuk a dan b, contoh akta notaris, surat gugat, dan putusan hakim.

Dalam berbagai literatur Indonesia banyak dikenal berbagai istilah seperti perundangan, perundang-undangan, peraturan perundang-undangan, dan peraturan negara, sedangkan dalam kepustakaan Belanda dikenal istilah wet, wetgeving, wettelijke regels, atau wettelijke regeling (en).Istilah Perundangundangan berasal dari istilah wettelijke regels. Berbeda dengan istilah peraturan negara yang merupakan terjemahan dari staatsregeling, istilah staats berarti negara, dan regeling adalah peraturan. Istilah 'perundangan' berasal dari kata 'undang', bukan berasal dari kata 'undang-undang'. Kata 'undang' tidak memiliki konotasi dengan pengertian 'wet' atau 'undang-undang', karena istilah 'undang' mempunyai arti tersendiri. Adapun yang dimaksud dengan peraturan negara adalah peraturan-peraturan tertulis yang diterbitkan oleh instansi resmi baik dalam pengertian lembaga atau Pejabat tertentu.

Istilah 'peraturan perundang-undangan' digunakan oleh A. Hamid S. Attamimi, Sri Soemantri, dan Bagir Manan. Menurut A. Hamid S. Attamimi, istilah tersebut berasal dari istilah wettelijke regels atau wettelijke regeling, namun istilah tersebut tidak mutlak digunakan secara konsisten. Ada kalanya istilah 'Perundang-undangan' saja yang digunakan. Penggunaan istilah 'peraturan perundang-undangan' lebih relevan dalam pembicaraan mengenai 
jenis atau bentuk peraturan (hukum), namun dalam konteks lain lebih tepat digunakan istilah perundang-undangan, misalnyadalam menyebut teori perundang-undangan, dasar-dasar perundang-undangan, dan sebagainya. Adapun pengertian peraturan perundang-undangan adalah sebagai berikut:

a) Menurut M. Solly Lubis, Peraturan perundangan adalah peraturan mengenai tata cara pembuatan peraturan negara.(Lubis, 1989: 2).

b) Menurut T.J. Buys, Perundang-undangan sebagai peraturan-peraturan yang mengikat secara umum (algemeenbindendevoorschriften).

c) Menurut A. Hamid S. Attamimi, Peraturan perundang-undangan adalah peraturan negara di tingkat pusat dan di tingkat daerah yang dibentuk berdasarkan kewenangan perundang-undangan baik bersifat atribusi maupun bersifat delegasi.(Lubis, 1989: 2).

d) Menurut Bagir Manan, Peraturan perundang-undangan ialah setiap putusan tertulis yang dibuat, ditetapkan dan dikeluarkan oleh lembaga dan atau pejabat negara yang mempunyai (menjalankan) fungsi legislatif sesuai tata cara yang berlaku.(Lubis, 1989: 2).

e) Pasal 1 angka 2 Undang-Undang Nomor 12 Tahun 2011 tentang Pembentukan Peraturan Perundang-undangan, Peraturan Perundangundangan adalah peraturan tertulis yang memuat norma hukum yang mengikat secara umum dan dibentuk atau ditetapkan oleh lembaga negara atau pejabat yang berwenang melalui prosedur yang ditetapkan dalam Peraturan Perundang-undangan.

Adapun yang termasuk dalam peraturan perundang-undangan untuk saat ini adalah sebagaimana yang dimaksud dalam Pasal 7 ayat (1) dan Pasal 8 ayat (1) Undang-Undang Nomor 12 Tahun 2011 tentang Pembentukan Peraturan Perundang-undangan.

Selain peraturan perundang-undangan, dalam kehidupan bernegara kita juga menemukan berbagai peraturan kebijakan, seperti Surat Edaran, Pedoman Kerja, Petunjuk Pelaksanaan (Juklak), Petunjuk Tekhnis (Juknis). Berbagai peraturan kebijakan tersebut muncul sebagai wujud penyelenggaraan tugas administrasi 
negara. Peraturan kebijakan termasuk dalam rumpun perundang-undangan semu (pseudowetgeving).

Awal mula perundang-undangan semu (pseudowetgeving)lahir di Belanda. Diduga muncul sebagai bentuk tindakan tata usaha negara yang menyimpang dari apa yang menjadi kewenangannya (penyimpangan hukum). Konsepperundang-undangan semu (pseudowetgeving) tentunya tidak dapat lepas dari diskresi (freiesermessen). Diskresi adalah keputusan dan/atau tindakan yang ditetapkan dan/atau dilakukan oleh pejabat pemerintahan untuk mengatasi persoalan konkret yang dihadapi dalam penyelenggaraan pemerintahan dalam hal peraturan perundang-undangan yang memberikan pilihan, tidak mengatur, tidak lengkap atau tidak jelas, dan/atau adanya stagnasi pemerintahan.Diskresi merupakan konsekuensi atas negara hukum kesejahteraan yang membebankan tugas yang sangat luas, yaitu menyelenggarakan kesejahteraan rakyat (WelfareState), kepada pemerintah. Tugas-tugas pemerintahan dapat diselenggarakan jika pemerintah diberi kebebasan untuk mengambil kebijakan sesuai dengan situasi dan kondisi faktual. Kebijakan-kebijakan pejabat administrasi negara itu kemudian dituangkan dalam bentuk peraturan kebijakan.

Meskipun dalam peraturan perundang-undangan tidak ada yang mendefenisikan peraturan kebijakan, namun setidaknya kita dapat mengacu pada pendapat para ahli, seperti berikut ini:

a. Laica Marzuki mendefinisikan peraturan kebijakan dengan mengacu padatiga komponen peraturan kebijakan, yaitu: Pertama, peraturan kebijakan dibuat oleh badan atau pejabat tata usaha negara sebagai perwujudan penggunaan diskresi dalam bentuk tertulis yang diumumkan keluar lalu mengikat para warga. Kedua, isi peraturan kebijakan memuat aturan umum tersendiri yang melampaui cakupan kaidah peraturan perundang-undangan yang dibuatkan pengaturan operasional. Ketiga, badan atau pejabat tata usaha negara yang membuat peraturan kebijakan tidak memiliki kewenangan perundangundangan.(Marzuki, 2010: 58).

b. Victor Imanuel dalam buku Konsep Uji Materil, mengutip pendapat Philipus M. Hadjon mengenai peraturan kebijakan. Menurut Philipus M. Hadjon, 
suatu peraturan kebijakan pada hakikatnya merupakan produk dari perbuatan tata usaha negara yang bertujuan menampakkan keluar suatu kebijakan tertulis tanpa didasarkan pada kewenangan pembuatan peraturan dari badan atau pejabat tata usaha negara yang menciptakan peraturan kebijakan tersebut.(Imanuel, 2013: 35).

c. Bagir Mananmemberikan pandangan mengenai peraturan kebijakan. Menurutnya salah satu ciri utama peraturan kebijakan adalah tidak adanya wewenang pemerintah membuat peraturan tersebut. Tidak adanya wewenang dalam hal ini perlu diinterpretasikan sebagai tidak adanya peraturan perundang-undangan yang secara tegas memberikan kewenangan pada pemerintah untuk mengeluarkan peraturan kebijakan tersebut. Walaupun tidak ada kewenangan yang diberikan namun seringkali permasalahan yang ada membuat pemerintah tidak dapat menyelesaikannya jika hanya berdasarkan peraturan perundang-undangan yang ada. Dalam sudut pandangan keadaan yang mendesak inilah peraturan kebijakan menjadi relevan untuk dibuat oleh pemerintah.

d. Darumurti peraturan kebijakan merupakan produk dari tindakan pemerintahan yang berkaitan dengan pelayanan publik yang harus diberikan pemerintah. Pemerintah dalam fungsinya memberikan pelayanan publik harus aktif berperan mencampuri bidang kehidupan sosial ekonomi masyarakat. Dengan demikian pemerintah tidak boleh menolak untuk bertindak dengan dalih terjadi kekosongan pengaturan hukum. (Darumurti, 2012: $57-58)$.

Peraturan kebijakan memiliki bentuk yang khas dan berbeda dengan peraturan perundang-undangan. Jika mengacu pada jenis peraturan perundangundangan dalam Undang-Undang Nomor 12 Tahun 2011, maka akan terlihat kekhasan bentuk peraturan kebijakan. Peraturan kebijakan dapat dibentuk dalam berbagai bentuk dokumen tertulis yang bersifat membimbing, menuntun, memberi arahan kebijakan, dan mengatur suatu pelaksanaan tugas dan pekerjaan.(Imanuel, 2013: 75). 


\section{B. Bentuk Produk Hukum Yang Dikelurkan Presiden}

Secara umum kewenangan Presiden berdasarkan UUD 1945 terbagi atas beberapa kewenangan seperti :

a. Kewenangan yang bersifat eksekutif atau kewenangan dalam penyelenggaraan pemerintahan berdasarkan undang-undang dasar;

b. Kewenangan yang bersifat legislatif atau kewenangan untuk mengatur kepentingan umum atau public;

c. Kewenangan yang bersifat judisial dalam rangka pemulihan keadilan yang terkait dengan putusan pengadilan, yaitu untuk mengurangi masa hukuman, pengampunan ataupun menghapuskan tuntutan yang terkait dengan kewenangan pengadilan;

d. Kewenangan bersifat diplomatik yaitu kewenangan dalam menjalin hubungan dengan negara lain atau subjek hukum internasional yang lainnya dalam konteks hubungan luar negeri, baik dalam keadaan perang atau damai; dan

e. Kewenangan bersifat administratif

Dalam menjalankan kewenangannya yang diatur dalam Undang-Undang Dasar Negara Republik Indonesia Tahun 1945 yaitu pada Pasal 4 ayat (1), Presiden berwenang mengeluarkan peraturan, penetapan serta dapat mengeluarkan kebijakan yang merupakan pelaksanaan dari kewenangan diskresinya. Dengan demikian, materi yang bisa diatur oleh Presiden terdiri atas:

a. Penetapan (beschikking);

b. Peraturan (regeling); dan

c. Peraturan kebijakan (beleidregel).

Dari ketiga bentuk tersebut, semuanya pernah dan ada dalam produk hukum yang pernah dikeluarkan presiden, yaitu dengan materi penetapan dalam bentuk keputusan presiden, dengan materi peraturan dalam bentuk peraturan presiden sedangkan dengan materi peraturan kebijakan dalam bentuk intruksi presiden. 


\section{Hierarki Peraturan Perundang-Undangan Di Indonesia}

Menurut Dendy Sugono sebagaimana dikutip oleh Rachmat Trijono, hierarki berarti urutan tingkat.(Trijono, 2013: 48) Sedangkan dalam Pasal 7 ayat (2) Undang-Undang Nomor 12 Tahun 2011 tentang Pembentukan Peraturan Perundang-undangan, hierarki adalah penjenjangan setiap jenis peraturan perundang-undangan yang didasarkan pada asas bahwa peraturan perundangundangan yang lebih rendah tidak boleh bertentangan dengan peraturan perundang-undangan yang lebih tinggi.

Dalam sejarah ketatanegaraan di Indonesia, hierarki peraturan perundangundangan di Indonesia mengalami beberapa kali perubahan. Pengaturan hierarki peraturan perundang-undangan dapat ditemukan pertama kali pada UndangUndang Nomor 1 Tahun 1950 tentang Peraturan-Peraturan Pemerintah Pusat. Pada Pasal 1 disebutkan bahwa "Jenis peraturan-peraturan pemerintah pusat ialah:

a. Undang-Undang dan Peraturan Pemerintah Pengganti Undang-Undang;

b. Peraturan Pemerintah;

c. Peraturan Menteri.

Pengaturan mengenai hierarki peraturan perundang-undangan kemudian diatur dalam Ketetapan Majelis Permusyawaratan Rakyat Sementara Republik Indonesia Nomor XX/MPRS/1966 tentang Memorandum DPR-GR mengenai Sumber Tertib Hukum Republik Indonesia dan Tata Urutan Peraturan Perundang-undangan Republik Indonesia. Dalam Tap MPRS ini disebutkan bahwa bentuk-bentuk peraturan perundangan Republik Indonesia menurut Undang-Undang Dasar 1945 ialah sebagai berikut:

a. Undang-Undang Dasar Republik Indonesia 1945;

b. Ketetapan MPR;

c. Undang-Undang/Peraturan Pemerintah Pengganti Undang-Undang;

d. Peraturan Pemerintah;

e. Keputusan Presiden; dan

f. Peraturan-Peraturan Pelaksana Lainnya, seperti 
- Peraturan Menteri;

- Instruksi Menteri;

- Dan lain-lainnya.

Hierarki peraturan perundang-undang kembali mengalami perubahan dengan keluarnya Ketatapan Majelis Permusyawaratan Rakyat Nomor III/MPR/2000 tentang Sumber Hukum dan Tata Urutan Peraturan Perundangundangan. Pada Pasal 2 disebutkan bahwa "Tata urutan peraturan perundangundangan merupakan pedoman dalam pembuatan aturan hukum di bawahnya. Tata urutan peraturan perundang-undangan Republik Indonesia adalah:

a. Undang-Undang Dasar 1945;

b. Ketetapan Majelis Permusyawaratan Rakyat Republik Indonesia;

c. Undang-Undang;

d. Peraturan Pemerintah Pengganti Undang-Undang;

e. Peraturan Pemerintah;

f. Keputusan Presiden yang bersifat mengatur;

g. Peraturan Daerah.

Pengaturan mengenai hierarki peraturan perundang-undangan kemudian berganti seiring dengan diundangkannya Undang-Undang Nomor 10 Tahun 2004 tentang Pembentukan Peraturan Perundang-undangan. Dalam Pasal 7 disebutkan bahwa "jenis dan hierarki peraturan perundang-undangan adalah sebagai berikut:

a. Undang-Undang Dasar Negara Republik Indonesia Tahun 1945;

b. Undang-Undang/Peraturan Pemerintah Pengganti Undang-Undang;

c. Peraturan Pemerintah;

d. Peraturan Presiden; dan

e. Peraturan Daerah.

Seiring dengan diubahnya Undang-Undang Nomor 10 Tahun 2004 menjadi Undang-Undang Nomor 12 Tahun 2011 tentang Pembentukan Peraturan Perundang-undangan, hierarki peraturan perundang-undangan juga mengalami perubahan. Pasal 7 ayat (1) Undang-Undang Nomor 12 Tahun 2011 tentang 
Pembentukan Peraturan Perundang-undangan menyebutkan bahwa "Jenis dan hierarki peraturan perundang-undangan terdiri atas:

a. Undang-Undang Dasar Negara Republik Indonesia Tahun 1945;

b. Ketetapan Majelis Permusyawaratan Rakyat;

c. Undang-Undang/Peraturan Pemerintah Pengganti Undang-Undang;

d. Peraturan Pemerintah;

e. Peraturan Presiden;

f. Peraturan Daerah Provinsi; dan

g. Peraturan Daerah Kabupaten/Kota.

Berdasarkan perkembangan hierarki peraturan perundang-undangan yang ada, dapat dilihat bahwa sebenarnya tidak pernah ada istilah instruksi presiden dalam hierarki peraturan perundang-undangan, yang ada adalah peraturan presiden dan keputusan presiden.

\section{Kedudukan Instruksi Presiden Dalam Hierarki Peraturan Perundang- Undangan}

Dari konsepsi ilmu perundang-undangan, menurut C. Waaldijk, suatu peraturan perundang-undangan yang memuat peraturan hukum (rechtsregels) harus memenuhi empat macam unsur yaitu sebagai berikut:(BPHN, 2010: 40).

a. subyek, yaitu orang atau instansi yang (tidak) harus ( moet) atau (tidak) boleh (mag) melakukan sesuatu;

b. karakter, yaitu unsur peraturan yang menyatakan sesuatu yang harus (moet), boleh (mag), tidak harus (niet moet) atau tidak boleh (niet mag) dilakukan;

c. obyek, yaitu perbuatan (gedraging) yang boleh (niet) atau tidak boleh (niet mag); dan

d. (mungkin) persyaratan-persyaratan (voorwaarden).

Waaldijk menjelaskan bahwa peraturan-peraturan (regels) tersebut dapat berupa peraturan-peraturan hukum (rechtsregels) atau peraturan-peraturan kebijakan (beleidsregels). Bagaimana membedakannya? Menurut ahli perundang-undangan itu, peraturan-peraturan hukum memiliki dasar hukum 
(grod)-wettelijke grodslag) untuk membentuknya dan mempunyai kekuatan yuridis secara langsung (direct juridisch bindend). (BPHN, 2010: 41).

Peraturan-peraturan kebijakan tidak memiliki dasar hukum untuk menetapkannya, dan (karena itu) tidak memiliki kekuatan mengikat secara langsung. Peraturan kebijakan dibentuk oleh organ pemerintah dan diperlukan oleh organ pemerintahan (bestuursorgaan) untuk melaksanakan suatu kewenangan pemerintahan (bestuursbevoegdheid). Maka secara tidak langsung, melalui penerapan prinsip-prinsip pemerintahan yang patut (beginselen van behoorlijk bestuur), seperti asas kepercayaan (vertrouwensbeginsel) dan asas persamaangelijkheidsbeginsel, peraturan kebijakan tersebut dapat dipinjam juga sebagai instrumen untuk menetapkan hak dan kewajiban, sehingga peraturan kebijakan disebut sebagai peraturan semu (pseudo-wetgeving).(BPHN, 2010: 41).

Menurut Jimly Asshiddiqie, ada tiga bentuk pengambilan keputusan yang dibedakan menjadi:(Asshiddiqie, 2010: 10)

a. Pengaturan yang menghasilkan peraturan. Biasanya disebut dengan "peraturan";

b. Penetapan menghasilkan ketetapan atau keputusan. Yang disebut dengan "keputusan" atau "penetapan"; dan

c. Penghakiman atau pengadilan yang menghasilkan vonis.

Lebih lanjut Jimly Asshiddiqie mengutip pendapat Michael Allen dan Brian Thompson, menyatakan bahwa peraturan kebijakan yang dapat juga disebut sebagai quasi legislation dapat dikelompokkan menjadi 8 (delapan) golongan, yaitu: (Asshiddiqie, 2010: 392)

a. Procedural rules (peraturan yang bersifat procedural);

b. Interpretative (petunjuk penafsiran);

c. Instruction to Officials (perintah atau instruksi, seperti Instruksi Presiden dsb);

d. Prescriptive/Evidential Rules;

e. Commendatory Rules;

f. Voluntary Codes; 
g. Rules of Practices, Rules of Management, or Rules of Operation;

h. Consultative Devices dan Administrative Pronouncements.

Aturan-aturan kebijakan ini memang dapat dibuat dalam berbagai macam bentuk dokumen tertulis yang bersifat membimbing, menuntun, memberi arahan kebijakan dan mengatur suatu pelaksanaan tugas dan pekerjaan. (Website Hukum Online).

\section{Penutup}

\section{A. Kesimpulan}

Instruksi presiden tidak masuk dalam hierarki peraturan perundangundangan. Hal ini dikarenakan, instruksi presiden bukan merupakan peraturan yang bersifat mengatur, instruksi presiden masuk ke dalam ranah peraturan kebijakan. Di mana fungsi dari peraturan kebijakan adalah untuk membimbing, menuntun, memberi arahan kebijakan dan mengatur suatu pelaksanaan tugas dan pekerjaan. Sehingga tidak ada sanksi yang dapat diberikan kepada pihak yang melanggar instruksi tersebut.

\section{B. Saran}

Apabila dianggap bahwa materi dari Instruksi Presiden Nomor 26 Tahun 1998 tentang Menghentikan Penggunaan Istilah Pribumi dan Non Pribumi penting dan masih perlu diatur. Disarankan agar materi muatannya dimasukkan ke dalam materi muatan undang-undang. Sehingga, lebih mempunyai kekuatan hukum yang mengikat dan dapat dimasukkan sanksi bagi siapa yang melanggar ketentuan tersebut. 


\section{Daftar Pustaka}

Erliyana, A., Keputusan Presiden; Analisis Keppres RI 1987 - 1998, Jakarta, Program Pascasarjana Fakultas Hukum Universitas Indonesia. 2004

Badan Pembinaan Hukum Nasional, Laporan Akhir Pengkajian Hukum tentang Eksistensi Peraturan Perundang-undangan di luar Hierarki Berdasarkan UU No. 10 Tahun 2004 tentang Pembentukan Peraturan Perundang-undangan, Jakarta, Badan Pembinaan Hukum Nasional. 2010

Pantja, I.G.,\& Na'a, S., Dinamika Hukum dan Ilmu Perundang-undangan di Indonesia, Bandung, Alumni. 2008.

Asshiddqie, J., Hukum Acara Pengujian Undang-Undang, Jakarta: Sinar Grafika. 2010.

Asshiddqie, J., Perihal Undang-Undang, Jakarta, Rajawali Pers. 2010.

Darumurti, K.D., Kekuasaan Diskresi Pemerintah, Bandung: Citra Aditya Bakti. 2012.

Marzuki, L., Peraturan Kebijakan (Beleidsregel): Hakikat serta Fungsinya Selaku Sarana Hukum Pemerintahan, Jakarta, Universitas Trisakti. 2010.

Dewi, L.R., dan Yaqin, A.Y., Mengenal Hukum melalui Pengantar Hukum, Serang, Dinas Pendidikan Provinsi Banten. 2012.

Lubis, M.S., Landasan dan Teknik Perundang-undangan, Bandung, Mandar Maju. 1989.

Rachmat Trijono, R., Dasar-Dasar Ilmu Pengetahuan Perundang-undangan, Jakarta, Papas Sinar Sinanti. 2013.

Ridwan H.R., Hukum Administrasi Negara, Jakarta, Raja Grafindo Persada. 2006.

Rahardjo, S., Ilmu Hukum, Bandung, Citra Aditya Bakti. 2000.

Dirdjosisworo, S., Pengantar Ilmu Hukum, Jakarta, Raja Grafindo Persada. 1994.

Imanuel, V., Konsep Uji Materil, Malang, Setara Press. 2013

Adisapoetra, R.K., Pengantar Ilmu Hukum Administrasi Negara, Jakarta: Pradnja Paramita. 1978. 
Website Hukum Online. http://www.hukumonline.com/klinik/detail/lt50cf397 74d2ec/peraturan-presiden, diakses pada 01 Oktober 2017, Pukul 10.00 WIB.

Website Jogja Tribun News. http://jogja.tribunnews.com/2017/10/17/hebohpidato-anies-istilah-pribumi-non-pribumi-dilarang-berdasarkan-inpresnomor-26-tahun-1998, diakses pada 01 Oktober 2017, Pukul 09.00 WIB. 